Shakespeare and Genre 


\title{
Shakespeare and Genre
}

From Early Modern Inheritances to Postmodern Legacies

\author{
EDITED By \\ ANTHONY R. GUNERATNE
}

palgrave
macmillan 


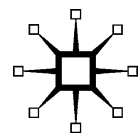

SHAKESPEARE AND GENRE

Copyright (C) Anthony R. Guneratne, 2011.

Softcover reprint of the hardcover 1st edition 2011 978-0-230-10898-1

All rights reserved.

First published in 2011 by

PALGRAVE MACMILLAN ${ }^{\circledR}$

in the United States-a division of St. Martin's Press LLC,

175 Fifth Avenue, New York, NY 10010.

Where this book is distributed in the UK, Europe and the rest of the world, this is by Palgrave Macmillan, a division of Macmillan Publishers Limited, registered in England, company number 785998, of Houndmills,

Basingstoke, Hampshire RG21 6XS.

Palgrave Macmillan is the global academic imprint of the above companies and has companies and representatives throughout the world.

Palgrave ${ }^{\circledR}$ and Macmillan ${ }^{\circledR}$ are registered trademarks in the United States, the United Kingdom, Europe and other countries.

ISBN 978-1-349-29188-5

ISBN 978-1-137-01035-3 (eBook)

DOI 10.1057/9781137010353

Library of Congress Cataloging-in-Publication Data

Shakespeare and genre : from early modern inheritances to postmodern legacies / edited by Anthony R. Guneratne.

p. $\mathrm{cm}$.

1. Shakespeare, William, 1564-1616-Literary style. 2. English language-Early modern, 1500-1700-Style. 3. Literary form.

4. Postmodernism (Literature) I. Guneratne, Anthony R.

PR3072.S34 2011

$822.3^{\prime} 3$ - dc23

A catalogue record of the book is available from the British Library.

Design by Newgen Imaging Systems (P) Ltd., Chennai, India.

First edition: December 2011

109876654321

Transferred to Digital Printing in 2013 
For you, dear friends, who have stood by me unwaveringly through bright midsummer nights' dreams and the darkest of winter's tales, who through many a tempest brought me calm, and who have showered me with kindness for which no repayment was expected or ever would suffice:

for you David Frasier, who have sent perhaps a thousand books and articles to whatever edge of the earth I happened to be clinging;

for you Elizabeth Shadigian, who have advised me for some thirty years and who once flew to Florida to rescue me from the state I then was in;

for you Lisa Cain, who have shared so much of your time and good humor, and so many of New York's boundless treasures with me;

and, most of all, for you Michelle Brown, who more than once helped me steer clear of life's grand canyons and minor molehills — had I but known what you would have to endure with such gentleness and courage, I would have found the strength to level the earth for you;

this book. 


\section{Contents}

List of Illustrations $\quad$ ix

Acknowledgments $\quad$ xi

Introduction: Kin, Kind, and Shakespeare's

Significance to Genre Studies $\quad 1$

Anthony R. Guneratne

Section 1 Shakespeare and Renaissance Genres

\section{Part I Origins and Conventions}

1 Shakespeare the Metalinguist

David Crystal

2 Murdering Peasants: Status, Genre, and the

Representation of Rebellion

Stephen Greenblatt

3 "The stage is hung with black": Genre and the Trappings of Stagecraft in Shakespearean Tragedy

Andrew Gurr

\section{Part II Shakespeare's Deployments of Genre}

4 Shakespeare's Development of Theatrical Genres:

Genre as Adaptation in the Comedies and Histories

David Bevington

5 The Shakespeare Remix: Romance, Tragicomedy, and

Shakespeare's "distinct kind"

Lawrence Danson 


\section{Part III Shakespeare and the Reconfiguration of Genre in Performance}

6 Turning Genre on Its Head: Shakespeare's Refashioning of His Sources in Richard III, King Lear, and The Winter's Tale Stephen J. Lynch

7 Shakespearean Comedy, Tempest-Toss'd: Genre, Social Transformation, and Contemporary Performance Diana E. Henderson

\section{Section 2 Shakespeare and Contemporary Genres Part I Shakespeare and Culturally Specific Genres}

8 Comical Tragedies and Other Polygeneric Shakespeares in Contemporary China and Diasporic Chinese Culture Alexander C. Y. Huang

9 King Lear East of Berlin: Tragedy under Socialist Realism and Afterwards Alexander Shurbanov and Boika Sokolova

\section{Part II Shakespeare-based Genres in Other Media}

10 Shakespeare and Film Genre in the Branagh Generation Samuel Crowl

11 Genre and Televised Shakespeare: Evolving Forms and Shifting Definitions

Tony Howard

12 Shakespeare and Media Allegory

Peter S. Donaldson

\section{Part III Shakespeare as Genre}

13 Shakespeare among the Philosophers

Charles Martindale

14 "I'll teach you differences": Genre Literacy, Critical

Pedagogy, and Screen Shakespeare

Douglas M. Lanier 


\section{Illustrations}

Front Cover: Detail of Traumgesicht, aquarelle on paper, by Albrecht Dürer. Courtesy of the Kunsthistorisches Museum, Vienna. Detail of facing pages from the front matter of Folger Folio No. 68 of the First Folio (1623) of the plays of William Shakespeare. Courtesy of the Folger Shakespeare Library.

1 Detail of the facing pages of Shakespeare's First

Folio (1623), containing the commendatory verse by

Ben Jonson and a frontispiece engraving by Martin

Droeshout. Courtesy of the Folger Shakespeare Library.

xvi

2 "Monument to Commemorate a Victory" (in Albrecht

Dürer's The Painter's Manual, 1525). Fig. 1 from

"Murdering Peasants." Courtesy of the Library of Congress.

3 "Memorial to a Drunkard" (in Albrecht Dürer's

The Painter's Manual, 1525). Fig. 2 from "Murdering

Peasants." Courtesy of the Library of Congress.

4 "Monument to Commemorate a Victory over the

Rebellious Peasants," upper section (in Albrecht

Dürer's The Painter's Manual, 1525). Fig. 3a from

"Murdering Peasants." Courtesy of the Library of Congress.

5 "Monument to Commemorate a Victory over the

Rebellious Peasants," lower section (in Albrecht

Dürer's The Painter's Manual, 1525). Fig. 3b from

"Murdering Peasants." Courtesy of the Library of Congress.

6 "The Man of Sorrows Seated," title page from

Albrecht Dürer's The Little Passion, 1511. Fig. 4 from

"Murdering Peasants." Courtesy of the Library of Congress.

7 "Traumgesicht" ("Dream of an Inundation") by Albrecht

Dürer. Aquarelle on paper. Fig. 5 from "Murdering

Peasants." Courtesy of the Kunsthistorisches Museum, Vienna. 


\section{Acknowledgments}

The heart set on such a task as addressing the full range of Renaissance genres, even as we know them today, will surely be riven by heavy doses of tragedy, comedy, tragicomedy, romance, and pastoral, and, after a two-year gestation, quite a bit of history as well. Mine was. The tragedy was the most obvious and, inevitably, keenly felt. Those that befell me seem scarcely worth mentioning, but the work of a year stretched to another as the extraordinary, stoic individuals who contributed to this volume faced sorrow, illness, and the passing of those dearest to them. These pages represent not merely a triumph of brilliance, which, for such an assembly of renowned scholars, should be taken for granted, but also of fortitude and perseverance. For my own part, these pages also chronicle the loss of friends and collaboratorsperhaps an inevitability in vast, time-sensitive, collective endeavors-but some of those I lost happened to be in the nearest place I have ever had to a home, Bloomington, and in the case of one dear friend, Helga Keller, the loss was not even to this book but to sheer misfortune. And there were those from afar as well, like my one-time editor Sascha Talmor and my gentle, generous cousin Preeni Jayasinghe. The list grows even as we go to press.

History is so much easier to relate. In hindsight, one might be able to place the origins of this book in the 1980s, from a course devoted to adaptations of the Faust legend that I had taken as a graduate student from Peter Boerner, and another devoted to the proliferation of genres in the Age of Romanticism offered by Ernst Bernhardt-Kabisch. Or then again, it might have sprung from a thousand random conversations, or the gift of two books (years apart) made by Harry Geduld, one a smart black-bound quarto reprint of the Hamlet of 1605, and the other one just as black but scarcely larger than half the length of my little finger, a minute First Folio version of the same play. Surely, the section on Hamlet to be found in the introduction has something to do with these acts of generosity, which will be acknowledged with a dedication to another book, hopefully not as long in coming.

No doubt the determined sleuth will trace the actual inception of this book to my graduate seminars on "Genres in Popular Culture" at the National University of Singapore (1996-1999), for it is in many ways a response to the probing questions asked by the often brilliant interlocutors 
among my students there. Some of the theorists whose ideas contribute to these pages, Bakhtin, Todorov, and Derrida, were already well established in genre studies in the late 1990s, and we debated their ideas and those of scholars of film and other media as if they were recent interventions and provocations, which for the most part they were. Another key figure for us, Hayden White, whom I knew as a contributor to a journal issue that I edited, has remained a prolific, insightful advocate of genre studies. Likewise, Umberto Eco's finest contributions to genre studies are of more recent vintage, but having been a student of semiotics with Thomas Sebeok at Indiana University, I was introduced early to Eco's thought and not much later to him, often encountering him in full flight when - ignoring the sabbatical granted for the writing of Foucault's Pendulum - he would pop in to contribute to his seminar at the DAMS faculty of the University of Bologna. (Through him I also met Jurij Lotman, who at his invitation, gave a lecture on genre, history, and semiotics at the University of Bologna in the year I spent there as a student of Carlo Ginzburg and Guido Fink, also thinkers and writers about genre.) In much the same interventionist fashion, it was Bakhtin's first American translator-interpreter, Michael Holquist, who perhaps noting my bemused reaction to a thesaurus I had been given as a prize by my department, presented me with a copy of the recently translated The Dialogic Imagination, in which was scribbled the hope that this work might mean more to me. It became an essential part of my own students' curriculum in Singapore. One of the most responsive, Khoo Sim Eng, was later to become a colleague and is now both a professor and administrator who commissioned my most recent course guideline for "Shakespeare and film." It was perhaps inevitable that in writing about sound on film, my doctoral student Virginia Wells has chosen to delve into Shakespeare's histories.

The publishers of Shakespeare's quartos were often in two minds as to the genres of the plays they published: Troilus was designated as both history and tragedy in 1609 and the Richard plays were only reclassified as histories in 1623. For some five years or more, I have also bounced ideas off Richard Vela, a close friend and collaborator, although as time passed, our schedules and priorities never seemed to mesh (and our final attempt to meet and work together achieved a truly tragicomical conclusion). For the most part, I prefer the comedies and the romances whose endings Shakespeare contrived to make happy ones, and, for the most part, this book has led to unusually happy experiences, especially during the times I have been able to pursue work funded through grants and fellowships awarded by institutions in which I have placed great store. My own, Florida Atlantic University, granted me a sabbatical that allowed me to complete the work for this book (while doing research toward two others) in addition to awarding me a Morrow Grant, funding my travel to three major film archives in Los Angeles. Faculty from a number of institutions supported 
my letters of application for further fellowships during my sabbatical year, often setting time aside that they could barely afford and so winning a lifetime's gratitude: James Naremore and Peter Bondanella, distinguished emeritus professors from Indiana University; Kristin Thompson from the University of Wisconsin; Clare Carroll from SUNY's Graduate Center; and Jan-Christopher Horak from UCLA. A special thanks for both reading my work and writing in support of it is due Michael Anderegg, a generous colleague of many years. The Everett Helm fellowship granted by the Lilly Library of Indiana University allowed me to complete some of my research there, and a Franklin Grant by the American Philosophical Society made it possible for me to pursue research at the Biblioteque Nationale in Paris, at the Eye Film Institute of the Nederlands Film Museum, at the British Library, at the British Film Institute, and even at the Theatre Archive of the University of Bristol, where I was able to track down one of the contributors, Charles Martindale. These were such extraordinary experiences that I will have occasion to thank members of their staff individually in a subsequent work that will result from their endeavors: this book surely merits as many thanks from and to its contributors as any that may be due from me.

I would be remiss, however, not to include a very special note of gratitude to David Carnegie for reading this volume's introduction in detail, for making the most constructive comments imaginable, and for reassuring me at a moment when all seemed sheer chaos. We met as fellows of the Folger Shakespeare Library some seven years previously, and I remember his kindness (and that of his late wife, Pauline) vividly; nor was I surprised to find it, or his unfailing good humor, undiminished. The final touches were added to Shakespeare and Genre during the late spring of 2011, spent in the Capitol Hill district of Washington D. C., during which I received the final contributions and drafted the concluding sections of the book. Among other Folger fellows of newer vintage, I have to thank Jeremy Lopez and Anne Coldiron for saving me oodles of time with good advice and Jean-Christophe Mayer for helping with a multitude of tasks and for having such a charming and talented wife, Hélène. (Well, he did see the book in preparation, as did Ian Gadd, both with keen, critical eyes and sharp pencils.) Far, far too many members of the Folger staff have contributed to my research to be mentioned individually (as many will be in a book devoted to the research sponsored by the Folger Library), but some have given much to this one also. The most comprehensive thanks should perhaps go to Carol Brobeck for reading my fellowship application and to Gail Kern Paster for approving it. This is the second fellowship I have received during Gail's tenure, and it is with great regret that I will see her hand over the reigns to the next head of the library. Steven Ellis has been helpful and optimistic throughout, as has David Schalkwyk. Jennifer Rahm's amusing candor has been inspiring. Georgiana Ziegler's deft illustration of the uses of the Folger Library's meticulous online catalogue eased many tasks, as 
did Jim Kuhn's occasional intercessions in this regard, and Steven Galbraith surely deserves commendation for help with the pun that would not brook "casting off" too lightly. A very special word of thanks is due to Erin Blake. An eloquent and busy writer on illustrated Shakespeare, she manufactured time to help: all of the illustrations in this book show her deft touch at finding them, and one, the Folger Folio No. 68, is from her own institutional collection. Another work she uncovered, the 1538 Folger edition of Dürer's The Painter's Manual, furnishes many of the illustrations to the section headings, and it is due to Renata Mesmer's translations of passages in the book that I was able to locate the correct illustrations within minutes from the 1525 original held by the Library of Congress (she has also translated sections that will contribute to a talk at the Folger). I owe much to the latter institution, especially to Zoran Sinobad at the library's remarkable film archive-his advice and material assistance has been essential to my work on this and other books. Margaret Kirckhofer, who oversaw the duplication of the book's illustrations, and Everett Larson of the Hispanic Division, who helped me track down Borges's short stories, have also played a role in the completion of this truly international and multicultural work in the nation's capitol.

Naturally, the pastoral aspect of this work came mixed with romance and comedy, in small villages on the banks of the Danube (where I thought through this book and another), in two university towns and, paradoxically, in a number of big cities where such places as Lincoln Park and the Cloisters have provided refuges. It was in Bloomington that I once got to know the late Morgan Brown, whose amazing daughter Michelle set aside her own sorrows yet again to set my heart alight almost as soon as I returned to my "hometown," as it were. I prepared a dish for her own freshly fledged daughter, Sabine, and was grateful to have the offering made on my little finger sampled and then to have the finger nipped into the bargain. I appreciate the efforts of Chris Jaffe and Steve Volan, who helped with lodging and transportation and much else besides (Steve also helped typeset the printed articles of Greenblatt and Gurr and, in the end, even agreed to follow my complex template for the various divisions of the book). Reconnecting with another adopted family, the Hofstadters, renewed my spirits and enlivened the precious moments snatched between mouthfuls at suppertime conversations, although Monica and Danny, and their dad Douglas, contrived only to nip my conscience from time to time. I not only enjoy Antonella Borghi's terraced apartment when I visit Bologna, but have spent time in contemplation (time she had to set aside from work) when I traveled with her to the island gardens of Lago Maggiore. Not long afterward, when I imagined myself more ill than perhaps I was, my high school friend, now Dr. Elizabeth Shadigian, curtailed her participation at a conference to fly (sans stethoscope) from Washington to my home in Jacksonville to cure what turned out to be a wounded spirit. During my extended stay in Washington, my hosts, the redoubtable Anne McLean and 
Melih Kutluer, have been unfailingly generous. Milvia Gutierrez and the staff of the Hyatt Regency Bonaventure have been no less solicitous during my Fort Lauderdale sojourns. My family in Jacksonville, especially my young nephew and niece Rajiv and Anita, deserve praise for unusually mature patience and forbearance as I wrote this book, as does my sister, Chinta, for locating and posting crucial materials to me, and most of all, my father Rex, who has actually financed much of the research toward this and two forthcoming books. To all of them, and to my great friends whose hospitality I enjoy oftenHarold Kaufler (abetted by Gari Rubino), who treat me as if I were some rare avian species on its annual archive-ward migration when I land at the verdant Palms in Los Angeles, Stuart Diamond and Nevena Silic, with whom I have delighted in sojourns in New York and who are a rich font of good ideas and warm fellowship, as well as to my cheerful and cheering companion from the Metropolitan Museum, Lisa Cain, who has made my days there and in Washington brighter-I owe more thanks than space in this book allows.

To bring this mixed history to a close, I should start by acknowledging that this book could not have gone to press on schedule had not permission for reprinting articles come from two obliging groups of people. The new version of "Murdering Peasants" appears with the kind permission of the editors of the journal Representations (where it appeared in the inaugural issue of 1983), which was secured through the intercessions of associate editor Jean Day and Rebecca Wells of the University of California Press. Andrew Gurr's "The stage was hung with black" appeared in its original form in Acts of Criticism: Performance Matters in Shakespeare and His Contemporaries (2006), edited by Paul Nelsen and June Schlueter, and it appears herein with the kind permission of Julien Yoseloff of Associated University Presses (whose alacrity in granting it is due to Harry Keyishian's generous intervention). My own indexing and editing have been shepherded with aplomb by Rebecca Francescatti, the staff of Newgen (with Deepa John overseeing the eagle-eyed copyediting and illustrative verve), and that of Palgrave-Macmillan, especially Heather Faulls of production and Joanna Roberts, with whom I consulted on matters of permissions. I do not think I need permission to thank Brigitte Shull, who made sure the book proposal I presented her, with abstracts of all the articles, copies of works to be reprinted, and many of my own explanations, received prompt reviews that were as sensitive and sensible as they were insightful. Far more than the layout and the beautiful cover can be attributed to her forethought and guidance.

Note: The title of any play has been given in full in order to avoid any confusion about conflicting abbreviations. Quotes from Shakespeare's plays are taken from the most recent edition of The Norton Shakespeare, unless otherwise specified in the notes to each chapter. For reasons of economy, directors and release dates of adaptations are included only in the first instance the title appears. 


\section{To the Reader.}

\section{This Figure, that thou here feeft put,}

It was for gentle Shakefpeare cur;

Wherein the Grauer had a ftrife

with Nature, to out-doo the life :

$\mathrm{O}$, could he but haue dravwne his wit

As well in braffe, as he hath hit

Hisface; the Printwoubd thenfurpaffe

All, that vvas euer vvrit in braffe.

But, fince he cannot, Reader, looke

Nor on his Picture, bur his Booke.

B. I.

Figure 1 Detail of the facing pages of Shakespeare's First Folio (1623), containing the commendatory verse by Ben Jonson (left page) and a frontispiece engraving by Martin Droeshout (right page).

Source: The Folger Shakespeare Library (First Folio No. 68). 


\section{Mr. VVILLIAM \\ SHAKESPEARES COMEDIES, HISTORIES, \& TRAGEDIES.}

Publifhed according to the True Originall Copies.

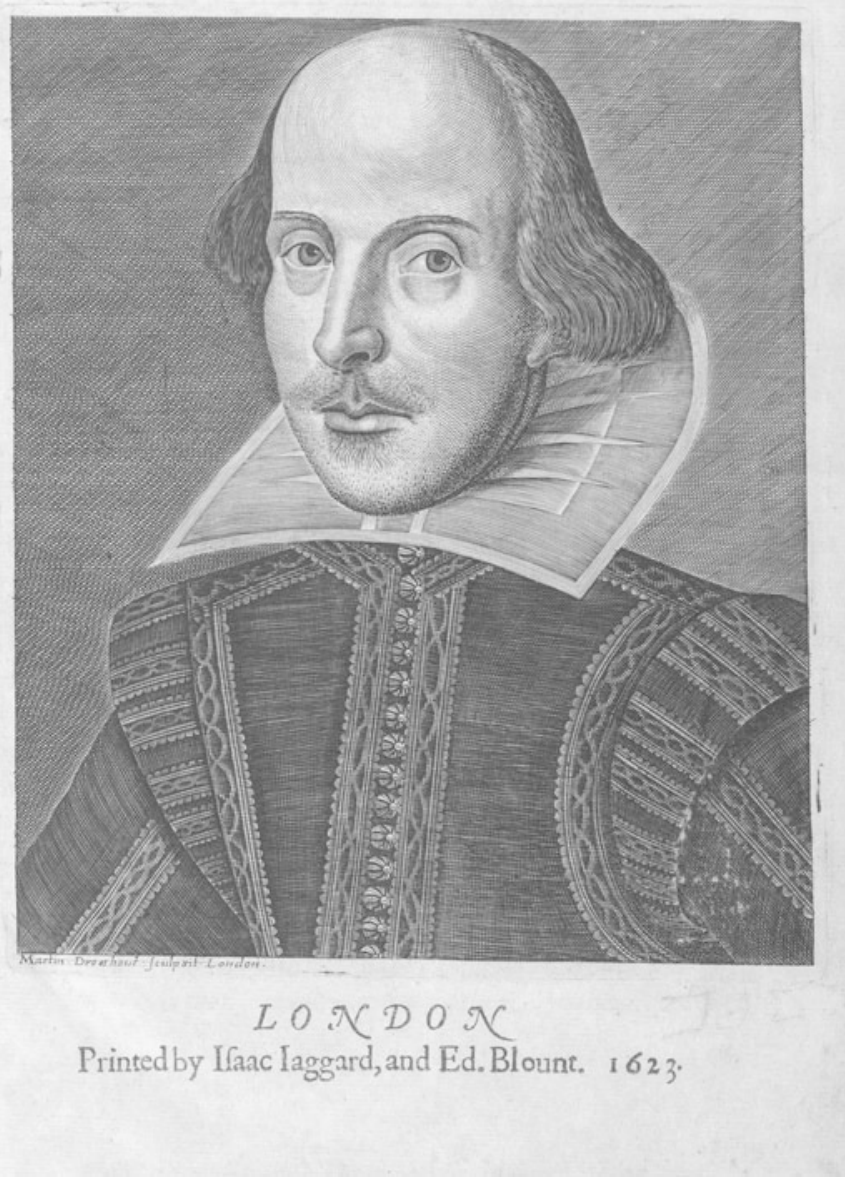

